\title{
Temporal Regulation of Ovine Interferon-tau Gene by the Transcription Factor Eomesodermin in the Peri-Implantation Period
}

\author{
Min-Su Kim, Hyun-Joo Lim, Ji Hwan Lee, Tae Young Hur and Jun Kyu Son* \\ Dairy Science Division, National Institute of Animal Science, RDA, Cheonan 31000, Korea
}

Received October 31, 2019

Revised November 19, 2019

Accepted December 10, 2019

*Correspondence

Jun Kyu Son

E-mail: junkyuson@korea.kr

ORCID

https://orcid.org/0000-0002-6266-3606

\begin{abstract}
Interferon tau (IFNT) regulation, an anti-luteolytic factor produced by conceptuses of the ruminant ungulates, is essential for the maintenance of early pregnancy, but a definitive mechanism for its temporal transcription has not been elucidated. We and others have observed the T-box protein eomesodermin (EOMES) exhibited high mRNA expression in the ovine embryonic trophectoderm; thus, both caudal-relatedhomeobox-2 (CDX2) and EOMES coexist during the early stages of conceptus development. Objective of this study was to examine the effect of EOMES on ovine IFNT gene transcription when evaluated with CDX2, ETS2 and AP1 transcription factors implicated in the control of cell differentiation in the trophectoderm. In this study, quantitatively via reverse transcription-polymerase chain reaction (RTPCR) analysis between ovine trophoblast cells was initially performed, finding that transcription factors CDX2 and 'EOMES transcription factor mRNAs' were specific to trophectoderm cells. These mRNAs were also found in days 15, 17, and 21 ovine conceptuses. Furthermore, human choriocarcinoma JEG3 cells (trophoblast cell line) were cotransfected with an ovine IFNT (-654bp)-luciferase reporter (-654-olFNT-Luc) construct and several transcription factor expression plasmids. Cotransfection of the reporter construct with CDX2, ETS2 and AP1 increased transcription of -654-olFNTLuc by about 11-fold compared with transfection of the construct alone. When cells were initially transfected with EOMES followed by transfection with CDX2, ETS2 and/ or AP1, the expression of -654-olFNT-Luc was decreased. Also, EOMES factor inhibited the stimulatory activity of $\mathrm{CDX} 2$ alone. These results suggest that when conceptuses attach to the uterine epithelium, ovine IFNT gene transcription is down-regulated by an increase of EOMES factor expression in the attached ovine trophoblast cells.
\end{abstract}

Keywords: interferon-tau, JEG3, transcription factor, transfection, trophectoderm

\section{INTRODUCTION}

Interferon-tau (IFNT) is known as a major conceptus protein that initiates the process of maternal recognition of pregnancy in ruminant ungulates. For a pregnancy to be established, conceptus recognition by the mother through physical and/or biochemical signaling is required, and is known as the process of maternal recognition of pregnancy (Short et al., 1969). IFNT, produced by peri-implantation blastocysts, is a major protein involved in the process of maternal recognition of pregnancy in ruminant ungulates (Godkin et al., 1982; Imakawa et 
al., 1987; Roberts et al., 1992). IFNT is secreted into the uterine lumen by the mononuclear trophectoderm of the conceptus (Roberts et al., 1992; Imakawa et al., 2004). IFNT acts to decrease endometrial oxytocin and estrogen receptors, which attenuates episodic prostaglandin $\mathrm{F}_{2 a}$ $\left(\mathrm{PGF}_{2 \mathrm{a}}\right)$ secretion and in turn results in the prevention of luteolysis (Vallet et al., 1988; Spencer and Bazer, 1996). Secretion of ovine IFNT (oIFNT) starts on day 8-9 of pregnancy (day $0=$ day of estrus), peaks on day $16-17$, and then declines rapidly (Godkin et al., 1982; Ashworth et al., 1989; Farin et al., 1989).

Expression of trophoblast IFNT is regulated in a temporal and spatial manner. However, molecular mechanisms by which IFNT gene transcription is regulated in this manner have not been fully elucidated. In the 5'-upstream sequences of the ovine IFNT gene, there is a promoter region with an ETS2 binding site at the equivalent location of the bovine counterpart. Ezashi et al. (1998) demonstrated that the transcription factor ETS2 binds to the promoter region from -79 to -70 bases (transcription-initiation site is +1 ) of the bovine IFNT gene, and that ETS2 transactivates a bovine IFNT-reporter construct in human choriocarcinoma JAR cells. In addition, the 5'-upstream region of the IFNT gene, ovine IFNT, which has been extensively studied by Yamaguchi et al., (1999; 2001), by transient transfection of reporter constructs with deleted or mutated 5'-upstream regions of the ovine IFNT gene in human choriocarcinoma JEG3 cells, an AP1 recognition binding site in the distal enhancer region (between -654 and -555) bases was shown to be effective in ovine IFNTreporter transactivation (Yamaguchi et al., 1999; 2001). Moreover, a transcription coactivator, cAMP-response element binding protein (CREB)-binding protein (CREBBP), the formation of a protein complex between CREBBP, $\mathrm{AP} 1$, and ETS2 is required for IFNT gene transcription (Xu et al., 2003). Also, the unique expression of the IFNT gene could be mainly regulated by CDX2 (Imakawa et al., 2006; Sakurai et al., 2009; 2010). It was also shown that caudaltype homeobox transcription factor 2 (CDX2) is expressed in the ovine and bovine trophoblasts during the conceptus elongation period (Degrelle et al., 2005; Imakawa et al., 2006).

Furturemore, Guillomot et al. (1990) and Imakawa et al. (2006) demonstrated that IFNT expression decreased as the trophoblast attached to the uterine epithelium. Degrelle et al. (2005) demonstrated that T-box protein eomesodermin (EOMES) expression is located in embryonic and extra-embryonic tissues of bovine elongating conceptuses. The EOMES is a prime candidate for IFNT gene down-regulation because it is expressed in the trophectoderm lineage and is thought to perform essential functions in trophectoderm development in mice and ovine and bovine (Hancock et al., 1999; Russ et al., 2000; Sakurai et al., 2009; Sakurai et al., 2013). These findings indicate that the attachment of trophectoderm to the uterine epithelium could be an important determinant for the decrease in IFNTexpression. Therefore, the present study was to find a transcription factor involved in the regulation of IFNT genes, reverse-transcriptase PCR were used to study various transcription factor mRNAs in Days 15, 17, and 21 trophoblasts of pregnancy. Also, we examined a direct relationship, if any, between EOMES and other transcription factors, which have been shown to be involved in ovine IFNT gene transcription, on ovine IFNT expressios. Therefore, objectives of this study were to demonstrate that EOMES is involved in transcription of the ovine IFNT gene, and to elucidate molecular mechanisms by which ovine IFNT gene transcription could be down-regulated through EOMES factor expression during the peri-implantation period.

\section{MATERIALS AND METHODS}

\section{Animals and RNA extraction and RT-PCR}

Conceptus tissues were supplied by the Laboratory of Animal Breeding at the University of Tokyo. Total RNAs from on the days 15, 17 and 21 conceptuses tissues (80 to $100 \mathrm{ng}$ ) were extracted using Isogen Reagent (Nippon Gene, Toyama, Japan) according to the protocol provided by the manufacturer. The RNA extracted from each sample then underwent reverse transcription (RT) into cDNA using oligo(dT) 12-18 primers and SuperScript II (Gibco BRL Life Technologies, Rockville, MD) according to the protocol suggested by the manufacturer, and these RT products were used as templates for PCR analysis. Levels of IFNT, CDX2, and EOMES mRNAs in peri-implantation conceptuses were examined by PCR with specific primers (Table 1). The PCR mixture consisted of $1 \mu \mathrm{L}$ of RT product, $1 \mu \mathrm{L}$ of 10X PCR buffer, $0.4 \mu \mathrm{L}$ each of forward and reverse primers $(10 \mathrm{pM}), 0.2 \mu \mathrm{L}$ of dNTP mixture $(10 \mathrm{mM})$, $0.3 \mu \mathrm{L}$ of $\mathrm{MgCl}_{2}(50 \mathrm{mM}), 6.6 \mu \mathrm{L}$ of $\mathrm{ddH}_{2} \mathrm{O}$, and $0.1 \mu \mathrm{L}$ of Taq DNA polymerase ( $5 \mathrm{U} / \mu \mathrm{L}$; Invitrogen, Carlsbad, CA). 
Table 1. Oligonucleotide primers for RT-PCR analysis

\begin{tabular}{lllc}
\hline $\begin{array}{c}\text { Gene } \\
\text { name }\end{array}$ & $\begin{array}{c}\text { Accession } \\
\text { gene bank }\end{array}$ & \multicolumn{1}{c}{$\begin{array}{c}\text { Primer of forword } \\
\text { and reverse }\end{array}$} & Length (bp) \\
\hline IFNT & M60903 & $\begin{array}{l}\text { F: cagaaagactttggtcttcc } \\
\text { R: agtgcagagctgctccagga }\end{array}$ & 166 \\
CDX2 & XM_871005 & $\begin{array}{l}\text { F: tatcaccatccggaggaaag } \\
\text { R: gagggctaggtcagctggta }\end{array}$ & 414 \\
EOMES & XM_001251923 & $\begin{array}{l}\text { F: actggttcccactggatgag } \\
\text { R: cacagcaatgaactgcgttt } \\
\text { F: ctcttccagcttccttcct } \\
\text { R: gggcagtgatctctttctgc }\end{array}$ & 226 \\
& BC102948 & 178 \\
\end{tabular}

The PCR was performed under the following conditions: $94^{\circ} \mathrm{C}$ for $5 \mathrm{~min}$, followed by 30 cycles of $94^{\circ} \mathrm{C}$ for $1 \mathrm{~min}$, $57^{\circ} \mathrm{C}$ for $1 \mathrm{~min}$, and $72^{\circ} \mathrm{C}$ for $1 \mathrm{~min}$. The PCR product was analyzed by electrophoresis on $1 \%$ agarose gel stained with ethidium bromide. ACTB mRNA was used as an internal control.

\section{Plasmid constructions}

The upstream region of ovine IFNT (IFNT, Nephew et al., 1993: GenBank accession number M60903) between -654 and $-51 \mathrm{bp}$ and its transcription factor binding site mutants were amplified through polymerase chain reaction (PCR) with specific primers (Yamaguchi et al., 1999). The PCR product was inserted into the pGL3 basic vector (Promega), consisting of a firefly luciferase gene. All expression vectors, pSG5 (Promega)-based constructs, were driven by the SV40 promoter/enhancer. These plasmid constructs were each confirmed to have expected nucleotide sequences by dideoxy sequencing.

\section{Cell culture and transient transfection}

Human choriocarcinoma JEG3 cells (HTB36, American Type Culture Collection) were cultured in Dulbecco's modified Eagle's medium (DMEM; Sigma-Aldrich, St. Lois, MO) supplemented with $10 \%(\mathrm{v} / \mathrm{v})$ fetal bovine serum (FBS; Sigma-Aldrich), $40 \mathrm{U} / \mathrm{mL}$ penicillin, and $40 \mu \mathrm{g} / \mathrm{mL}$ streptomycin under $5 \% \mathrm{CO}_{2}$ at $37^{\circ} \mathrm{C}$. One day before transient transfection was performed, JEG3 cells were re-plated onto 24 -well plastic culture plates and at $60 \%-70 \%$ confluency, they were transiently transfected with reporter construct and/or expression plasmids using Trans-Fast (3 $\mu \mathrm{L}$, cationic lipids, Promega) according to the manufacturer's protocol. In each well of 24-well plates, $1 \mu \mathrm{g}$ total plasmid DNA was added in duplicate (12 treatments/plate, $\mathrm{n}=4)$ in $200 \mu \mathrm{L}$ DMEM. After $1 \mathrm{hr}$ incubation at $37^{\circ} \mathrm{C}, 1$ $\mathrm{mL}$ of DMEM containing 10\% FBS was added to each well and transfected cells were cultured for $48 \mathrm{hr}$. To normalize transfection efficiency, pRL-TK vector (containing herpes simplex virus thymidine kinase promoter and $R e-$ nilla luciferase gene, Promega) along with each of pGL3 vector was transfected into JEG3 cells. The ratio of pGL3 vector to $\mathrm{pRL}$-TK vector was optimized at $160: 1$ (800 ng : $5 \mathrm{ng}$ ). In co-transfection experiments, plasmids of pGL3 vector (800 $\mathrm{ng}$ ), expression vector (in total of $140 \mathrm{ng}$ ) and pRL-TK vector (5 ng) were added to the medium. When two or more kinds of expression vectors were cotransfected, the ratio of these plasmids were $1: 1: 1$ (35 $\mathrm{ng}$ : $35 \mathrm{ng}: 35 \mathrm{ng})$. Throughout cotransfection studies, total amounts of expression plasmids were kept constant using the pSG5-based empty plasmid. For a $0 / 24 \mathrm{~h}$ transfection experiment, the initial transfection at $0 \mathrm{~h}$ was performed as aforementioned. At $24 \mathrm{~h}$ of incubation, the medium containing $10 \%$ FBS was replaced with medium without FBS, and transfection of an expression plasmid(s) was performed in the same manner. These cells were incubated for 24 more hours.

\section{Nuclear protein extraction, Western blot analyses}

Nuclear proteins were extracted from expression constructs-transfected JEG3 cells $\left(5 \times 10^{6}\right.$ cells) following the protocol described by Matsuda et al. (2004). Concentrations of nuclear extracts were determined using Bio-Rad Protein Assay Dye Reagent Concentrate (Bio-Rad Laboratories, Hercules, CA). $10 \mu \mathrm{g}$ nuclear extracts were loaded onto each lane and separated by $10 \%$ SDS-polyacrylamide gel electrophoresis (SDS-PAGE). Proteins in the gel were transferred onto Polyvinylidene difluoride (PVDF) membrane (pore size: $0.45 \mu \mathrm{m}$, Millipore, Bedford, MA) using electro-blotting method (Matsuda et al., 2004) and then treated with rabbit polyclonal antibody against the DNA binding domain of N-terminus of human CDX2 (ab22586, $0.04 \mu \mathrm{g} / \mathrm{mL}$, Abcam, Cambridge, UK), of mouse EOMES (ab23345, $0.04 \mu \mathrm{g} / \mathrm{mL}$, Abcam, Cambridge, UK). The normal rabbit IgG (Sigma-Aldrich) was used for negative control. The membrane was treated with the secondary antibody, horseradish peroxidase conjugated anti-rabbit, anti-goat or anti-mouse donky IgG (Amersham Pharmacia Biotech, Buckinghamshire, UK) and then detected by ECL western blotting detection system (Amersham Pharmacia Biotech). 


\section{Statistical analysis}

The results of luciferase assays were expressed as means \pm SEM. Differences in fold activation (luciferase activity) were examined by ANOVA, followed by multiple comparisons using Fisher's least significant difference test.

A

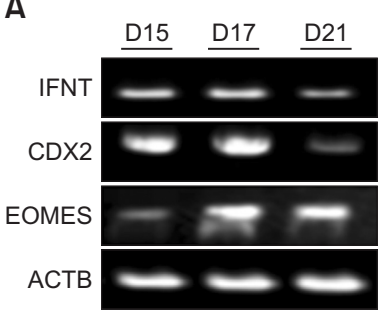

B

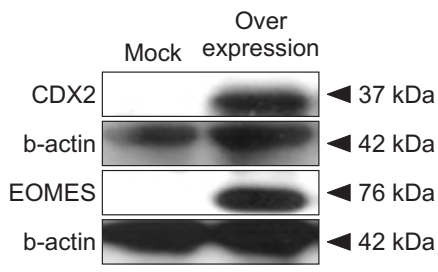

Fig. 1. Semi-quantitative RT-PCR showing the presence of transcription factor mRNAs in the ovine conceptuses and western blots showing proteins produced from expression vectors. (A) Relative amounts of IFNT, CDX2 and EOMES mRNAs in on day 15,17 , and 21 ovine conceptuses. RNAs extracted from frozen bovine conceptuses were analyzed for the presence of these transcripts using RT-PCR. (B) The efficacy of all pSG5-based CDX2 and EOMES expression vectors was examined via transient transfection into JEG3 cells, from which nuclear proteins (cell lysates) were isolated and subjected to western blot analysis with three independent replications. ACTB was used as the internal control.

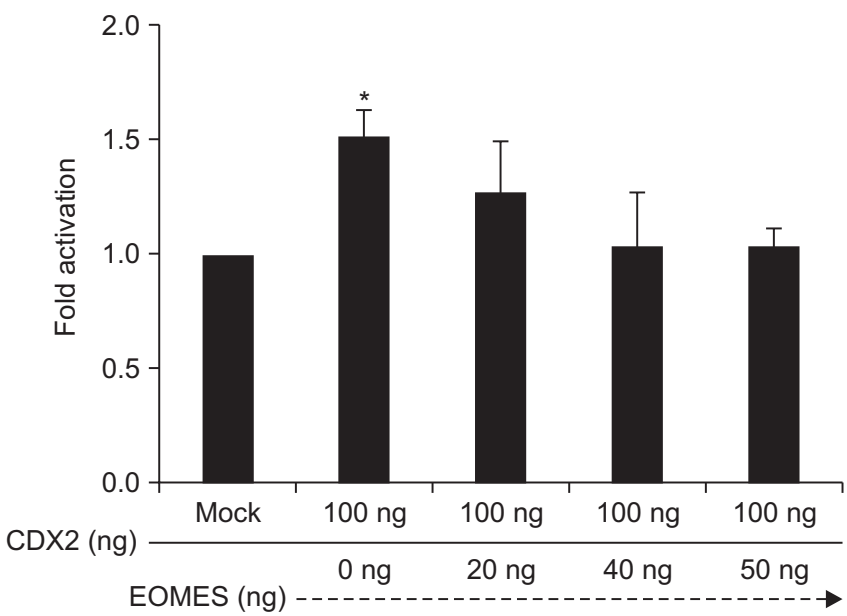

\section{RESULTS}

\section{Co-existence of CDX2 and EOMES mRNA, and proteins from expression constructs}

Levels of CDX2 mRNA were highest on days 15 and 17 conceptuses, of which expression pattern was similar to that of IFNT mRNA. Strong expression of EOMES mRNA was detected on days 17 and 21 of gestation (Fig. 1A). Efficacy of pSG5 based-CDX2 and/or EOMES expression vectors were examined through the transient transfection into JEG3 cells from which nuclear proteins (cell lysates) isolated were subjected to western blot analysis: All expression constructs exhibited proteins of expected sizes (Fig. 1B).

\section{Effects of EOMES on IFNT gene transcription in JEG3 cells}

To examine the effect of CDX2 and/or EOMES on ovine IFNT gene transcription, the -654-oIFNT-Luc construct with each or combination of transcription factor, was cotransfected into JEG3 cells, and luciferase activities were measured (Fig. 2). Luciferase activity increased about 50\% from the control (Mock) when CDX2 (100 ng) along expression plasmid was present. However, when JEG3 cells were cotransfection of CDX2 (100 ng) expression plasmid with EOMES (20 to $50 \mathrm{ng}$ ), The degree of transcriptional activation of the IFNT gene was gradually decreased by a EOMES expression plasmid. Whereas, when EOMES (100

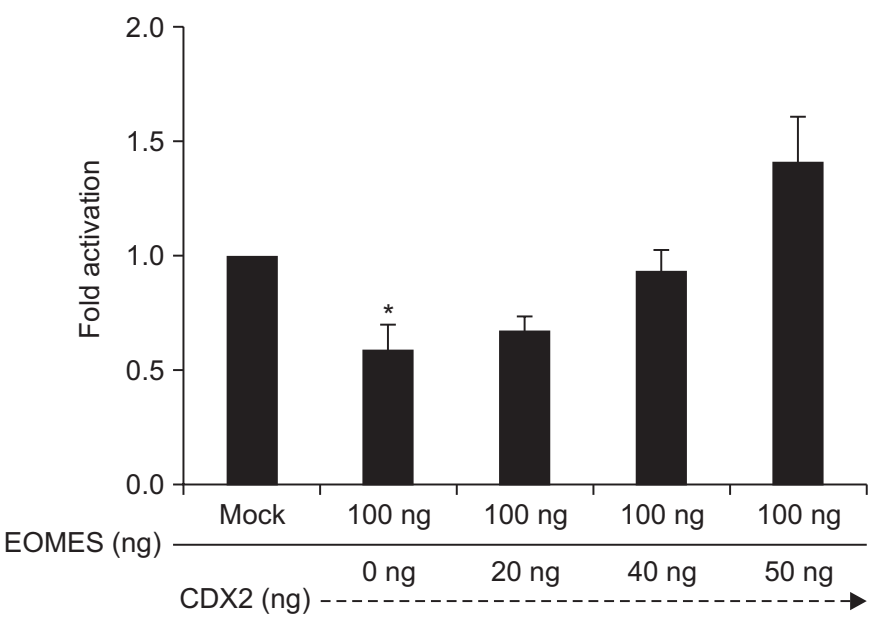

Fig. 2. Changes in the degree of ovine IFNT-reporter transactivation by EOMES and CDX2. Relationships of upstream of respective genes on the pSG-CDX2, and/or coactivator pSG-EOMES were tested by the expression level of luciferase. Luciferase-reporter plasmids (-654-oIFNT-Luc) containing the upstream region (positions -654 bp to +51 bp) were cotransfected into JEG3 cell with combination of pSG-CDX2, and/or pSG-EOMES. Luciferase activities are expressed as fold increase relative to those of control (-654-olFNTLuc construct) and the data are show as means \pm SEM ( $n=4$ each). ${ }^{*} p<0.05$, when compared to the luciferase activity of Mock (transfrection control plasmid without a transcription factor cDNA). 
ng) along expression plasmid was present, Luciferase activity decreased about $40 \%$ from the control (Mock). But, the degree of transcriptional activation of the IFNT gene was gradually increased by a CDX2 expression plasmid, when JEG3 cells were cotransfected with the EOMES (100 ng) and CDX2 (20 to $50 \mathrm{ng}$ ) expression plasmid.

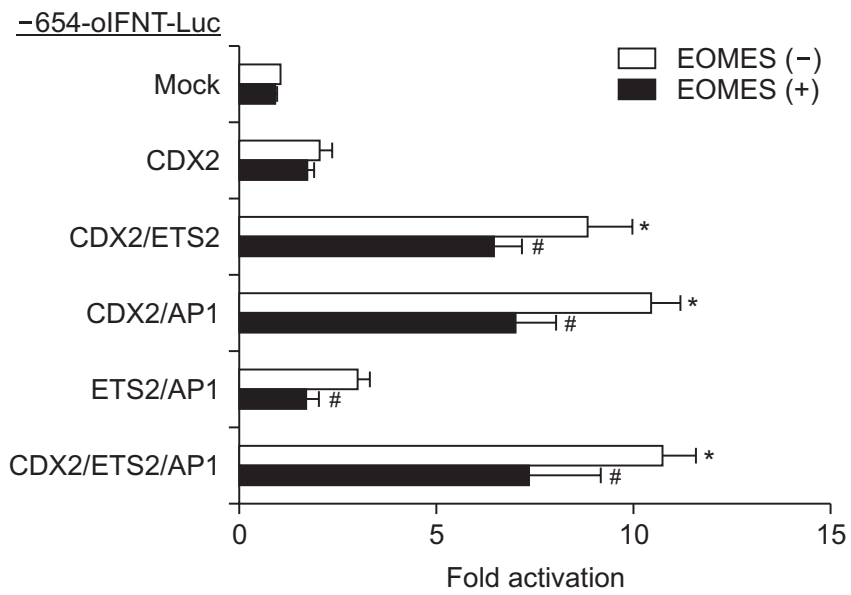

Fig. 3. Transativation assay of enhancer/promoter region of ovine IFNT-reporter gene. Relationships of upstream of respective genes on the CDX2, ETS2, AP1 and/or co-activator EOMES were tested by the expression level of luciferase. Luciferasereporter plasmids (-654-olFNT-Luc) containing the upstream region $(-654$ to +51$)$ were cotransfected into JEG3 cell with combination of CDX2, ETS2, AP1 and/or EOMES. Values represent means \pm standard error of the mean from three independent experiments, with replicates within an experiment. ${ }^{*} p$ $<0.05$, when compared to the luciferase activity of Mock. \#, Statistically significant difference in luciferase activity $(p<0.05)$ in the presence of Eomes expression plasmid.

\section{Effects of AP1, CDX2, ETS2 and EOMES on IFNT gene transcription in JEG3 cells}

To investigate whether EOMES had an effect on ovine IFNT gene transcription, the -654-OIFNT-Luc construct along with expression plasmids, AP1, ETS2 and/or CDX2, were transiently transfected into JEG3 cells, and luciferase activities were measured. In these data sets, the luciferase activity of the -654-oIFNT-Luc construct transfected with two or three expression plasmids increased approximately 9 to 11 -fold as compared to that of the the -654-oIFNTLuc construct alone (Fig. 3). EOMES exhibited an inhibitory effect on the the -654-oIFNT-Luc transcription when each of ETS2, AP1 and/or CDX2, or ETS2/AP1 together with the reporter construct was transfected into JEG3 cells. However, EOMES was not effective in suppressing the degree of the -654-oIFNT-Luc transcription when CDX2 along with EOMES was cotransfected into JEG3 cells.

\section{Examination of AP1, CDX2 and/or ETS2 binding sites on IFNT gene transcription}

To investigate whether each of three transcription factors, AP1, ETS2 and/or CREBBP, is required to bind the appropriate site of ovine IFNT genes, the binding sites of the the -654-oIFNT-Luc construct was mutated and transfected into JEG3 cells along with the three transcription factors. The the -654-oIFNT-Luc construct with any of binding site(s) mutated exhibited reduced luciferase activities (Fig. 4). Transcription factors, AP1, ETS2 and

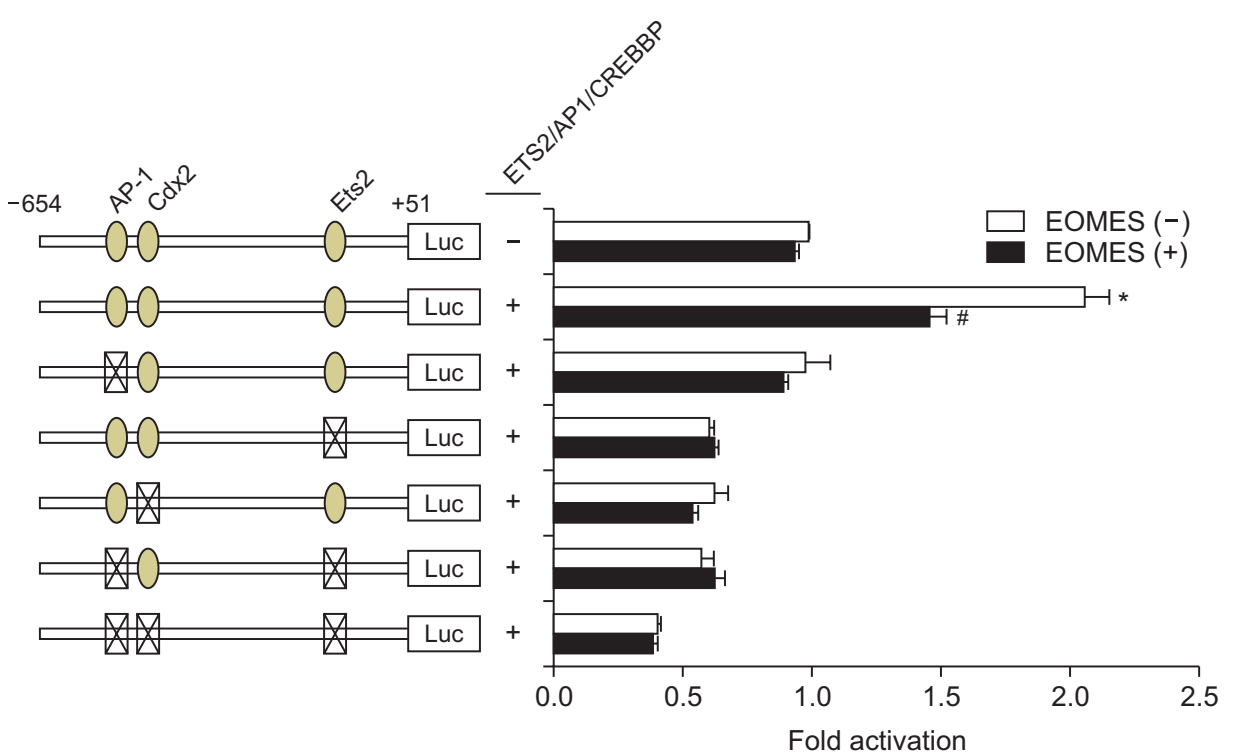

Fig. 4. Examination of the effect of transcription factor binding sites on IFNT gene transcription. The transcription factor binding site-mutated -654-olFNT-Luc construct cotransfected with AP1, ETS2 and CDX2 had reduced luciferase activities. In addition, cotransfection of EOMES expression plasmid along with AP1, ETS2 and CDX2 did not change the degree of luciferase activity, which had already been reduced due to mutated-transcription factor binding sites. Values represent means \pm standard error of the mean from three independent experiments, with replicates within an experiment. ${ }^{*} p<0.05$, when compared to the luciferase activity of Mock. \#, Statistically significant difference in luciferase activity $(p<0.05)$ in the presence of Eomes expression plasmid. 


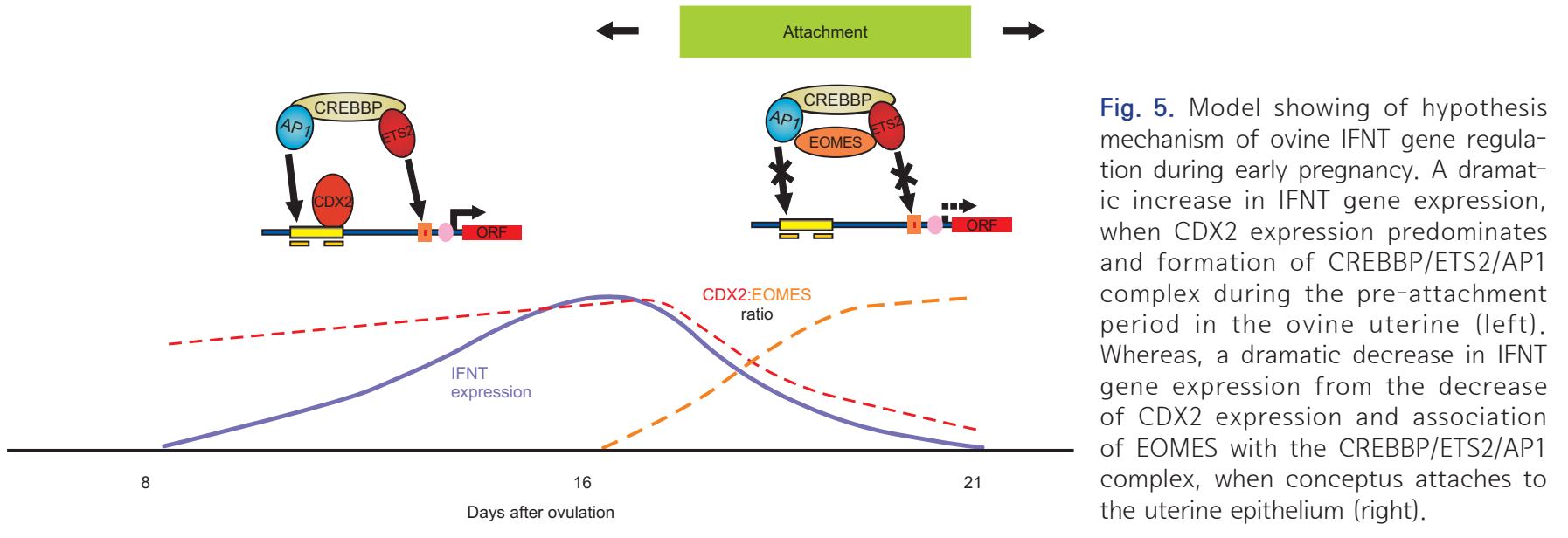

CREBBP, may form a complex(es) required for the ovine IFNT gene transcription, and each of complex components requires its binding to an appropriate site of the upstream region of ovine IFNT gene. In addition, cotransfection of EOMES expression plasmid along with AP1, ETS2 and CREBBP did not change the degree of luciferase activity, which had already been reduced due to mutated binding sites.

\section{DISCUSSION}

Expression of ovine interferon-tau, necessary for pregnancy establishment in ruminant ungulates, drastic increase followed by a rapid decrease during early pregnancy in the trophoblast. However, molecular mechanisms by which IFNT gene transcription is down-regulation in this manner have not been fully elucidated. It was predicted that EOMES expression subsides before the initiation of conceptus attachment (Sakurai et al., 2013). It appears now that EOMES expression does not subside before trophoblast attachment, rather, its expression may persist toward the period of placental formation (Kurosaka et al., 2004; Degrelle et al., 2005).

We demonstrated in this study was to examine the coexistence of CDX2 and EOMES mRNA in the days 15, 17 and 21 conceptuses. Expression for CDX2 predominated, compared to those for EOMES, during the period of maternal recognition of pregnancy (day 15-17). Coexpression of the CDX2 with EOMES mRNA was evident (day 15-21), CDX2 were highly expressed on day 15, 17 and expression was gradually weakly detectable on day 21 . However, the expression of other EOMES factor was weakly expressed on day 15 and expressed were highly detectable on day 17 and 21 ovine conceptuses (Fig. 1). Collectively, perhaps more interestingly, a conceptus specific and temporal pattern of gene expression was observed in this study. More specifically, there appears to be a transition from trophoblastic and CDX2 and EOMES factor expression. In addition, CDX2 and EOMES were a transcription factor associated with the up-regulation and down-regulation of ovine IFNT gene transactivation (Figs. 3 and 4). In this study, the relative abundance of transcription factor transcripts, which have been demonstrated to regulate ovine IFNT gene transcription, were evaluated. Luciferase activity assay resulted from the upstream region of ovine IFNT gene transfected to JEG3 cell reflected the transcripts of ovine IFNT gene in the utero. These results indicated that the expressions of ovine IFNT gene is regulated at transcriptional level and transient transfection analyses using JEG3 cell and also demonstrated that high and low expression levels from CDX2 and EOMES transcription factor, respectively.

The euchromatin state and transcription factor complex formation with AP1/CREBBP/ETS2 are required for the maximum IFNT transcription in human choriocarcinoma JEG3 cells (Ezashi et al., 1998, 2008; Xu et al., 2003; Imakawa et al., 2006; Kim et al., 2013). Among these factors, CDX2 was the most effective in increasing ovine IFNTreporter transactivation (Imakawa et al., 2006; Sakurai et al., 2009). Data from the present study indicate that cotransfection of CDX2 with ETS2 and AP1 into JEG3 cells, which possess CREBBP, but do not express CDX2, resulted in the greatest bovine and ovine IFNT gene transcription, supporting the finding that CDX2 is required for IFNT 
gene transcription (Imakawa et al., 2006; Sakurai et al., 2009). However, exhibited inhibitory effects of EOMES on ovine IFNT gene transactivation was observed even when CDX2 with ETS2 and AP1 were cotransfected with EOMES into JEG3 cells, indicating that the expected decrease in luciferase activity brought forth by CREBBP and either ETS2 and/or AP1 was down-regulated by EOMES transfection. Furthermore, AP1 with CDX2 and ETS2-like binding sites were demonstrated in the proximal promoter region of ovine IFNT and bovine IFNT genes (Ezashi et al., 1998; Yamaguchi et al., 2000; Imakawa et al., 2006; Sakurai et al., 2009; 2013). However, AP1-like binding site of the ovine IFNT gene promoter region were not detected.

Based on these observations, we propose the following molecular mechanism for ovine IFNT gene up-regulation down-regulation proceeds as follows (Fig. 5). These data suggest that increase in CDX2 is required for the degree of ovine IFNT gene transcription seen during the preattachment period. But, due to a decrease in the expression of CDX2 after attachment of conceptus to the uterine epithelium. Also, at the identical time, the expression of EOMES is increased, these results suggest that although EOMES did not bind directly to the promoter region of the ovine IFNT gene, EOMES then associate with the AP1 and CREBBP and ETS2 complex, negatively affecting its ability to maintain high ovine IFNT transcription, thus contribute to the down-regulation of ovine IFNT transactivation, for successful pregnancy.

\section{CONFLICTS OF INTEREST}

No potential conflict of interest relevant to this article was reported.

\section{ACKNOWLEDGEMENTS}

This work was carried out with the support of "Cooperative Research Program for Agriculture Science \& Technology Development (Project title: Development of data gathering and evaluation system for reproduction and milk component traits on dairy cattle in Korea, Project No. PJ01268901)" Rural Development Administration, Republic of Korea and supported by 2019 Postdoctoral Fellowship Program of National Institute of Animal Science, Rural Development Administration, Republic of Korean.

\section{AUTHOR'S AFFILIATION, POSITION AND ORCID NO.}

MS Kim, National Institute of Animal Science, Researcher, https://orcid.org/0000-0001-6237-3927

HJ Lim, National Institute of Animal Science, Researcher, https://orcid.org/0000-0001-7059-1553

JH Lee, National Institute of Animal Science, Researcher, https://orcid.org/0000-0002-0040-3104

TY Hur, National Institute of Animal Science, Researcher, https://orcid.org/0000-0003-3129-2942

JK Son, National Institute of Animal Science, Researcher, https://orcid.org/0000-0002-6266-3606

\section{REFERENCES}

Ashworth CJ, Bazer FW. 1989. Changes in ovine conceptus and endometrial function following asynchronous embryo transfer or administration of progesterone. Biol Reprod 40:425-433.

Degrelle SA, Campion E, Cabau C, Piumi F, Reinaud P, Richard C, Renard JP, Hue I. 2005. Molecular evidence for critical period in mural trophoblast development in bovine blastocysts. Dev Biol 288:448-460.

Ezashi T, Das P, Gupta R, Walker A, Roberts RM. 2008. The role of homeobox protein distal-less 3 and its interaction with ETS2 in regulating bovine interferon-tau gene expressionsynergistic transcriptional activation with ETS2. Biol Reprod 79:115-124.

Ezashi T, Ealy AD, Ostrowski MC, Roberts RM. 1998. Control of interferon- $\tau$ gene expression by Ets-2. Proc Natl Acad Sci USA 95:7882-7887.

Farin CE, Imakawa K, Roberts RM. 1989. In situ localization of mRNA for the interferon, ovine trophoblast protein-1, during early embryonic development of the sheep. Mol Endocrinol 3:1099-1107.

Godkin JD, Bazer FW, Moffatt J, Sessions F, Roberts RM. 1982. Purification and properties of a major, low molecular weight protein released by the trophoblast of sheep blastocysts at day 13-21. J Reprod Fertil 65:141-150.

Guillomot M, Michel C, Gaye P, Charlier N, Trojan J, Martal J. 1990. Cellular localization of an embryonic interferon, ovine trophoblastin and its mRNA in sheep embryos during early pregnancy. Biol Cell 68:205-211.

Hancock SN, Agulnik SI, Silver LM, Papaioannou VE. 1999. Mapping and expression analysis of the mouse ortholog of Xenopus Eomesodermin. Mech Dev 81:205-208.

Imakawa K, Anthony RV, Kazemi M, Marotti KR, Polites HG, Roberts RM. 1987. Interferon-like sequence of ovine trophoblast protein secreted by embryonic trophectoderm. Nature 330:377-379. 
Imakawa K, Chang K-T, Christenson RK. 2004. Pre-implantation conceptus and maternal uterine communications: Molecular events leading to successful implantation. J Reprod Dev 50:155-169.

Imakawa K, Kim M-S, Matsuda-Minehata F, Ishida S, Iizuka M, Suzuki M, Chang K-T, Echternkamp SE, Christenson RK. 2006. Regulation of the ovine interferon-tau gene by a trophoblastspecific transcription factor, Cdx2. Mol Reprod Dev 73:559-567.

Kim MS, Sakurai T, Bai H, Bai R, Sato D, Nagaoka K, Chang KT, Godkin JD, Min KS, Imakawa K. 2013. Presence of Transcription Factor OCT4 Limits Interferon-tau Expression during the Pre-attachment Period in Sheep. Asian-Aust. J. Anim. Sci 5:638-645.

Kurosaka S, Eckardt S, McLaughlin KJ. 2004. Pluriopotent lineage definition in bovine embryos by Oct4 transcript localization. Biol Reprod 71:1578-1582.

Matsuda F, Xu N, Kijima S, Tachi C, Christenson RK, Sakai S, Imakawa K. 2004. Analysis of transcriptional control elements in the 5 '-upstream region of ovine interferon-- $\tau$ gene using feeder-independent caprine trophoblast cell line, HTS-1. Placenta 25:166-175.

Nephew KP, Whaley AE, Christenson RK, Imakawa K. 1993. Differential expression of distinct mRNAs for ovine trophoblast protein-1 and related sheep type I interferons. Biol Reprod 48:768-778.

Roberts RM, Cross JC, Leaman DW. 1992. Interferons as hormones of pregnancy. Endocr Rev 13:432-452.

Russ AP, Wattler S, Colledge WH, Aparicio SA, Carlton MB, Pearce JJ, Barton SC, Surani MA, Ryan K, Nehls MC. 2000. Eomesodermin is required for mouse trophoblast development and mesoderm formation. Nature 404:95-99.

Sakurai T, Bai H, Bai R, Sato D, Arai M. 2013. Down-regulation of interferon tau gene transcription with a transcription factor, EOMES. Mol Reprod Dev 80:371-383.

Sakurai T, Bai H, Konno T, Ideta A, Aoyagi Y, Godkin JD, Imakawa K. 2010. Function of a transcription factor CDX2 beyond its trophectoderm lineage specification. Endocrinology 151:5873-5881.

Sakurai T, Sakamoto A, Muroi Y, Bai H, Nagaoka K, Tamura K, Takahashi T, Hashizume K, Sakatani M, Takahashi M, Godkin JD, Imakawa K. 2009. Induction of endogenous interferon tau gene transcription by CDX2 and high acetylation in bovine nontrophoblast cells. Biol Reprod 80:1223-1231.

Short RV. 1969. Implantation and the maternal recognition of pregnancy. In: GEW,Wolstenhome M, O'Connor editors. Foetal anatomy, Ciba Foundation Symposium. London: J\&A Churchill. pp 2-26.

Spencer TE, Bazer FW. 1996. Ovine interferon-t suppresses transcription of the estrogen receptor and oxytocin receptor genes in the ovine endometrium. Endocrinology 137:11441147.

Vallet JL, Bazer FW, Fliss MF, Thatcher WW. 1988. Effect of ovine secretory proteins and purified ovine trophoblast protein-1 on interoestrous interval and plasma concentrations of prostaglandin F-2a and E and of 13, 14-dihydro-15-keto prostaglandin F-2a in cyclic ewes. J Reprod Fertil 84:493504.

Xu N, Takahashi Y, Matsuda F, Sakai S, Christenson RK, Imakawa K. 2003. Coactivator CBP in the regulation of conceptus IFN $\tau$ gene transcription. Mol Reprod Dev 65:23-29.

Yamaguchi H, Ikeda Y, Moreno JI, Katsumura M, Miyazawa T, Takahashi E, Imakawa K, Sakai S, Christenson RK. 1999. Identification of a functional transcriptional factor AP1 site in the sheep interferon- $\tau$ gene that mediates a response to PMA in JEG3 cells. Biochem J 340:767-773.

Yamaguchi H, Katsumura M, Imakawa K, Sakai S, Christenson RK. 2000. Analysis of possible silencer elements of ovine interferon-tau gene. Endocr J 47:137-42.

Yamaguchi H, Nagaoka K, Imakawa K, Sakai S, Christenson RK. 2001. Enhancer regions of ovine interferon- $\tau$ gene that confer PMA response or cell type specific transcription. Mol Cell Endocrinol 173:147-155. 